Article

\title{
Influence of Tillage Practices and Crop Type on Soil $\mathrm{CO}_{2}$ Emissions
}

\author{
Darija Bilandžija *, Željka Zgorelec and Ivica Kisić \\ Received: 11 December 2015; Accepted: 11 January 2016; Published: 19 January 2016 \\ Academic Editor: Vincenzo Torretta \\ Department of General Agronomy, Faculty of Agriculture, University of Zagreb, Svetošimunska cesta 25, \\ Zagreb 10-000, Republic of Croatia; zzgorelec@agr.hr (Ž.Z.); ikisic@agr.hr (I.K.) \\ * Correspondence: dbilandzija@agr.hr; Tel.: +385-1-239-4089
}

\begin{abstract}
Nonsustainable agricultural practices often lead to soil carbon loss and increased soil carbon dioxide $\left(\mathrm{CO}_{2}\right)$ emissions into the atmosphere. A research study was conducted on arable fields in central lowland Croatia to measure soil respiration, its seasonal variability, and its response to agricultural practices. Soil C- $\mathrm{CO}_{2}$ emissions were measured with the in situ static chamber method during corn (Zea mays L.) and winter wheat (Triticum aestivum L.) growing seasons (2012 and 2013, $n=288$ ) in a field experiment with six different tillage treatments. During corn and winter wheat growing season, average monthly soil C- $\mathrm{CO}_{2}$ emissions ranged, respectively, from 6.2-33.6 and 22.1-36.2 $\mathrm{kg} \mathrm{ha}^{-1} \mathrm{day}^{-1}$, and were decreasing, respectively, from summer $>$ spring $>$ autumn and summer $>$ autumn $>$ spring. The same tillage treatments except for black fallow differed significantly between studied years (crops) regarding soil $\mathrm{CO}_{2}$ emissions. Significant differences in soil C-CO $\mathrm{CO}_{2}$ emissions between different tillage treatments with crop presence were recorded during corn but not during winter wheat growing season. In these studied agroecological conditions, optimal tillage treatment regarding emitted $\mathrm{C}-\mathrm{CO}_{2}$ is plowing to $25 \mathrm{~cm}$ along the slope, but it should be noted that $\mathrm{CO}_{2}$ emissions involve a complex interaction of several factors; thus, focusing on one factor, i.e., tillage, may result in a lack of consistency across studies.
\end{abstract}

Keywords: soil respiration; tillage; winter wheat; corn; climate change; Croatia

\section{Introduction}

Of many greenhouse gases, carbon dioxide is an important compound that affects the processes of global warming and is considered as an initiator of global climate change. In view of the heavy demands for agricultural production to meet the needs of the growing population, the role of agricultural practices and their impact on soil, climate, gaseous emission, water resources, biodiversity and others must be considered more now than in the past [1]. The soil as a potential sink for carbon can be a key factor in addressing climate change; it is the second- largest carbon reservoir, and contains twice as much carbon in relation to the atmosphere [2,3], three times more carbon compared to vegetation [4] and is also an important sink of atmospheric $\mathrm{CO}_{2}$ [5]. The reduction of $\mathrm{CO}_{2}$ emissions by soil carbon sequestration is of primary importance, as agricultural and forestry practices could remove atmospheric carbon by sequestration and thus mitigate climate change by maintaining and/or increasing the amount of carbon stored in the soil and plant material [6].

Soil respiration is estimated to be about $98 \mathrm{Pg} C$ per year, making it the largest contributor to $\mathrm{C}$ fluxes from terrestrial ecosystems to the atmosphere [7]. Soil respiration is the result of complex interactions between biotic and abiotic factors [8]. Excessive tillage, burning of crop residues, application of large amounts of fertilizers or changes in soil-air-water relation lead to higher $\mathrm{CO}_{2}$ emissions into the atmosphere and reduction of soil carbon content [9]. Studies have shown that factors 
such as agrotechnical measures, agroclimatic factors, physical, chemical and biological properties of the soil, presence and type of vegetation and many other factors have great influence on soil $\mathrm{CO}_{2}$ emissions [2,8,10-12].

Tillage has a very important impact on soil $\mathrm{CO}_{2}$ emissions [13]. Tillage causes a loss of organic carbon content of about $50 \%$ due to the stimulation of aerobic processes of microbial respiration [14]. Studies have shown contrasting results where $\mathrm{CO}_{2}$ emissions have been both decreased and increased by no-till compared with conventional tillage. Implementation of conventional tillage leads to changes in the soil profile and creates favorable conditions for the organic matter oxidation and mineralization processes, i.e., microbial degradation of plant and animal residues [15-18]. The intensity of tillage should be reduced in order to reduce the soil carbon loss. Many authors have determined higher soil $\mathrm{CO}_{2}$ emissions under conventional tillage compared to no-tillage [19-22], an increase in soil organic carbon content and lower soil $\mathrm{CO}_{2}$ emissions on no-tilled soils compared to conventional tilled soils [23] as no-tillage reduces the diffusion and content of air-filled pores in the soil, by which soil $\mathrm{CO}_{2}$ emissions are very low or non-existing [24]. On the other hand, implementation of no-tillage can increase soil $\mathrm{CO}_{2}$ emissions due to the maintenance of higher water content in the soil surface layer, which can result in greater soil biological activity. Higher soil $\mathrm{CO}_{2}$ emissions have been determined under no-tillage compared to conventional tillage [25-27].

The presence of vegetation also affects soil $\mathrm{CO}_{2}$ emissions, which can be $20 \%$ [28] or even $200 \%-300 \%$ times higher [10] in the soils with crop presence compared to black fallow. Soil $\mathrm{CO}_{2}$ emissions are also very dependent on the type and phenophases of crops which, by photosynthesis, absorb $\mathrm{CO}_{2}$ from the atmosphere [29-31]. Seasonal variability of soil $\mathrm{CO}_{2}$ emissions is determined in almost all types of ecosystems. Soil respiration is usually the highest in summer, decreases in the colder months and is the lowest in winter. The main factors affecting the seasonal variability may depend on the type of ecosystem and climate of the area. Largest impacts on seasonal variability mostly cause changes in the soil and air temperatures, the soil water content, photosynthesis and/or their interactions. In the spring, the temperature and soil water content are not limiting factors, which results in better crop growth and higher soil respiration. However, in summer, the soil water content is a limiting factor and, in winter, the soil temperature is a limiting factor which results in reduced crop growth and soil respiration. Higher soil $\mathrm{CO}_{2}$ emissions were determined in the warmer months compared to the colder months [22,32-34].

The aim of our study was to determine soil $\mathrm{CO}_{2}$ emissions and their seasonal patterns due to the lack of national data which could be used as input data for scientific predictions and impact assessments in the future. Furthermore, the aim was to determine the impact of six different tillage methods and vegetation types on soil $\mathrm{CO}_{2}$ emissions.

\section{Materials and Methods}

\subsection{Field Experiment}

The research was conducted on the experimental field that is located on the arable land near Daruvar $\left(\phi=45^{\circ} 33^{\prime} 54.22^{\prime \prime} \mathrm{N}, \lambda=17^{\circ} 01^{\prime} 45.07^{\prime \prime} \mathrm{E} ; 133\right.$ m.a.s.l.) and was initiated in 1994 , with the aim of determining soil degradation by water erosion. In 2012 the research was extended to the measurement of soil carbon dioxide emissions. The experimental field is located on a slope of $9 \%$, and tillage treatments differ according to the type, depth and direction of tillage. All tillage treatments were applied for corn in 2011-2012 and wheat in 2012-2013. Tillage treatments are:

- $\mathrm{BF}_{25}{ }^{\uparrow}$-black fallow, plowing $(25 \mathrm{~cm})$ along the slope every year.

- $\quad \mathrm{P}_{25}{ }^{\uparrow}$-sowing and plowing $(25 \mathrm{~cm})$ along the slope every year

- $\quad \mathrm{NT}^{\uparrow}$-no-tillage, sowing directly to the mulch along the slope.

- $\mathrm{P}_{25} \rightarrow$-sowing and plowing $(25 \mathrm{~cm})$ across the slope every year

- $\quad \mathrm{P}_{50} \rightarrow$-plowing $(25 \mathrm{~cm})$ every year + very deep plowing $(50 \mathrm{~cm})$ every three to four years across the slope (deep plowing was implemented in 2011). 
- $\mathrm{PS}_{50} \rightarrow$-plowing $(25 \mathrm{~cm})$ every year + subsoiling $(50 \mathrm{~cm})$ every three to four years across the slope (subsoiling was implemented in 2011).

\subsection{Soil Type}

Before the beginning of research, soil sampling $(0-25 \mathrm{~cm})$ was conducted in order to determine physical and chemical soil properties. Soil belongs to referent soil group of Stagnosol [35], containing $2 \%$ coarse sand, $59 \%$ fine sand, $24 \%$ silt, $15 \%$ clay. Soil $\mathrm{pH}_{\mathrm{KCl}}$ ranged depending treatments $3.8-4.2$, humus $0.5 \%-1.2 \%$, total nitrogen content $0.05 \%-0.08 \%$, water holding capacity $37.0 \%-38.8 \%$, soil porosity $38.9 \%-44.7 \%$ and bulk density $1.51-1.58 \mathrm{~g} \mathrm{~cm}^{-3}$.

\subsection{Climate}

Climate of the studied area is temperate continental [36]. According to the recent 30-year climate period 1981-2010, average annual air temperature in Daruvar is $11^{\circ} \mathrm{C}$, average annual precipitation is $902 \mathrm{~mm}$, snow cover can be expected from November to April, average annual air pressure is $999 \mathrm{hPa}$, average monthly relative humidity ranged from $71 \%$ to $85 \%$, evapotranspiration is $664 \mathrm{~mm}$ per year: water deficit occurs in August and surplus from November to April.

\subsection{Studied Cultures}

Studied cultures were corn (Zea mays L.) in 2012 and winter wheat (Triticum aestivum L.) in 2013. Tillage practices, fertilization of the fields, planting/harvesting dates, weed and pest control were done according to the traditional agricultural practices in the study area and are shown in Table 1.

Table 1. Field operations in production of studied cultures.

\begin{tabular}{|c|c|c|}
\hline \multicolumn{3}{|c|}{ Corn (Zea mays L.) } \\
\hline Date & Field Operation & Application \\
\hline 16 November 2011 & Fertilization & Urea $46 \%\left(200 \mathrm{~kg} \mathrm{ha}^{-1}\right)$; NPK 7:20:30 (400 $\left.\mathrm{kg} \mathrm{ha}^{-1}\right)$ \\
\hline 18 November 2011 & Primary tillage * & Ploughing to $25 \mathrm{~cm}$ depth \\
\hline 2 March 2012 & Fertilization & KAN $27 \%$ N $\left(250 \mathrm{~kg} \mathrm{ha}^{-1}\right)$ \\
\hline 29 April 2012 & Secondary tillage * & Disk plow; seedbed preparation \\
\hline 30 April 2012 & Sowing & 65,000 plants ha $^{-1}$ \\
\hline 1 May 2012 & Herbicide application & Radazin TZ $50\left(2.5 \mathrm{~L} \mathrm{ha}^{-1}\right)$; Herbotrof $\left(2.5 \mathrm{~L} \mathrm{ha}^{-1}\right)$ \\
\hline 1 October 2012 & Harvest & \\
\hline \multicolumn{3}{|c|}{ Winter wheat (Triticum aestivum $\mathrm{L}$. ) } \\
\hline Date & Field Operation & Application \\
\hline 25 October 2012 & Primary tillage * & Ploughing to $25 \mathrm{~cm}$ depth \\
\hline 26 October 2012 & Secondary tillage * & Disk plow; seedbed preparation \\
\hline 26 October 2012 & Sowing & $7,300,000$ plants $\mathrm{ha}^{-1}$ \\
\hline 6; 8; 25 March 2013 & Fertilization & KAN $27 \%$ N $\left(150 ; 200 ; 200 \mathrm{~kg} \mathrm{ha}^{-1}\right)$ \\
\hline 21 April 2013 & Herbicide and fungicide application & $\begin{array}{l}\text { Grandus }\left(24 \mathrm{~g} \mathrm{ha}^{-1}\right) \text {; Starane }\left(0.6 \mathrm{~L} \mathrm{ha}^{-1}\right) \text {; } \\
\text { Axial }\left(0.7 \mathrm{~L} \mathrm{ha}^{-1}\right) ; \text { Amistar extra }\left(0.8 \mathrm{~L} \mathrm{ha}^{-1}\right)\end{array}$ \\
\hline 14 May 2013 & Fungicide and pesticide application & Porto $\left(1.5 \mathrm{~L} \mathrm{ha}^{-1}\right)$; Lambda $\left(0.2 \mathrm{~L} \mathrm{ha}^{-1}\right)$ \\
\hline 18 July 2013 & Harvest & \\
\hline
\end{tabular}

\subsection{Measurement of Agroecological Factors and Soil $\mathrm{CO}_{2}$ Concentrations}

Field measurements of agroecological factors and $\mathrm{CO}_{2}$ concentrations (Figure 1) were conducted once per month, during two growing seasons in three repetitions at each tillage treatment. Total measurement number of soil $\mathrm{CO}_{2}$ concentrations and agroecological factors was 16 (nine from March to November 2012; seven from April to October 2013). Interpreted seasons of the year imply: spring (March-May), summer (June-August) and autumn (September-November). 
Measurements of soil $\mathrm{CO}_{2}$ concentrations were taken in early morning, time was consistent at all samplings and length of total measurement period was about $3 \mathrm{~h}$. Soil $\mathrm{CO}_{2}$ concentrations were measured by in situ static chamber method. Chambers were custom-made (Z. Zgorelec, Faculty of Agriculture University of Zagreb and Tukač company, 2011). They consists of two parts; a circular frame of the chamber and chambers cap (radius $25 \mathrm{~cm}$, height $9 \mathrm{~cm}$ ). At the beginning of measurement, circular frames were inserted $5 \mathrm{~cm}$ in the soil between the plants and the initial $\mathrm{CO}_{2}$ concentration at the soil surface was measured. Afterwards, the chambers were closed with caps and the incubation time was 30 minutes whereupon the accumulated $\mathrm{CO}_{2}$ in the closed chambers was measured. The soil $\mathrm{CO}_{2}$ concentrations were measured with portable infrared detector of carbon dioxide (GasAlerMicro5 IR, 2011). $\mathrm{CO}_{2}$ efflux $\left(\mathrm{kg} \mathrm{ha}^{-1}\right.$ day $\left.^{-1}\right)$ was afterwards calculated according to Bilandžija et al. [27] as:

$$
\mathrm{F}_{\mathrm{CO} 2}=\left[\mathrm{M} \times \mathrm{P} \times \mathrm{V} \times\left(\mathrm{c}_{2}-\mathrm{c}_{1}\right)\right] /\left[\mathrm{R} \times \mathrm{T} \times \mathrm{A} \times\left(\mathrm{t}_{2}-\mathrm{t}_{1}\right)\right]
$$

where: $\mathrm{F}_{\mathrm{CO} 2}-$ soil $\mathrm{CO}_{2}$ efflux $\left(\mathrm{kg} \mathrm{ha}^{-1}\right.$ day $\left.^{-1}\right)$; $\mathrm{M}$-molar mass of the $\mathrm{CO}_{2}\left(\mathrm{~kg} \mathrm{~mol}^{-1}\right)$; $\mathrm{P}$-air pressure (Pa); V-chamber volume $\left(\mathrm{m}^{3}\right)$; $\mathrm{c}_{1}$-initial concentration of $\mathrm{CO}_{2}\left(\mu \mathrm{mol} \mathrm{mol}{ }^{-1}\right) ; \mathrm{c}_{2}$-concentration of $\mathrm{CO}_{2}$ after incubation time $\left(\mu \mathrm{mol} \mathrm{mol}^{-1}\right)$; R-gas constant $\left(\mathrm{J} \mathrm{mol}^{-1} \mathrm{~K}^{-1}\right)$; T-air temperature $(\mathrm{K})$; A-chamber surface $\left(\mathrm{m}^{2}\right) ; \mathrm{t}_{2}-\mathrm{t}_{1}$-incubation period (day).

Air temperature and relative air humidity were measured with Testo 610 (2011), and air pressure with Testo 511 (2011) at height of $0.5 \mathrm{~m}$ above soil surface. Soil temperature and soil water content in the soil surface layer (10 cm depth) were measured with IMKO HD2 (2011), in the vicinity of each chamber.

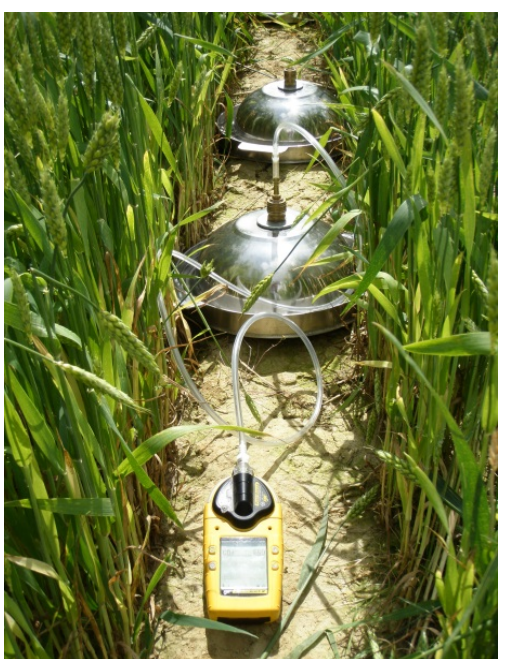

(a)

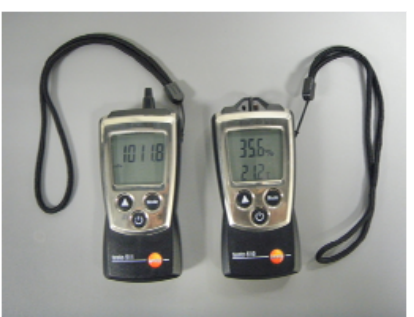

(b)

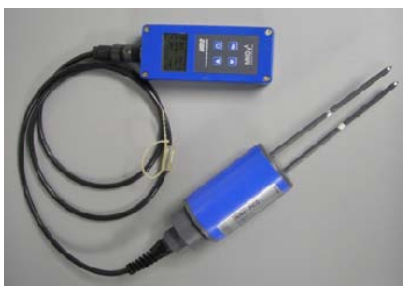

(c)

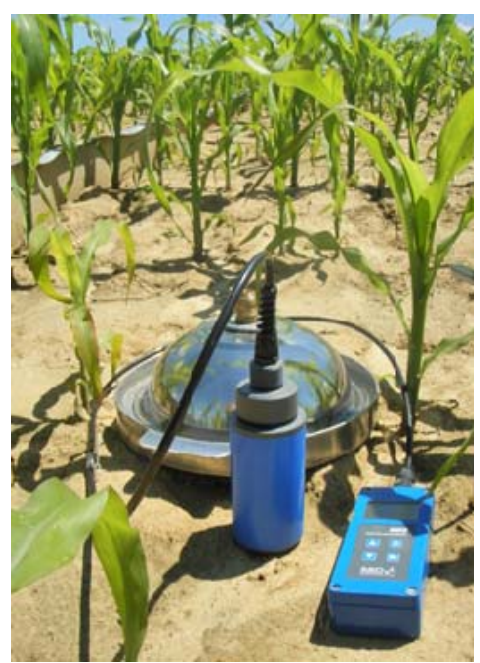

(d)

Figure 1. Measurement of agroecological factors and $\mathrm{CO}_{2}$ concentrations: (a) Field measurement of $\mathrm{CO}_{2}$ concentration; (b) Instruments for measurement of air parameters; (c) Instrument for measurement of soil parameters; (d) Field measurement of soil parameters.

\subsection{Statistical Analysis, Quality Management and Quality Control}

All data were analyzed using statistical Software SAS [37]. Variability between treatments were evaluated with analysis of variance (ANOVA) and tested, if it were necessary, with adequate post-hoc (Bonferroni) t-tests. In all statistical tests significance level was 5\%. Quality management (QM) system is in line with good laboratory practice and Internal and External (proficiency testing) quality control (QC) were included.

\section{Results and Discussion}

Analysis of variance (Table 2) showed that all of the studied factors have a significant impact on soil $\mathrm{C}-\mathrm{CO}_{2}$ emissions where the greatest impacts were found for: vegetation $(\mathrm{F}=169.3 ; p<0.0001)$, 
tillage $(\mathrm{F}=34.7 ; p<0.0001)$, time of measurement $(\mathrm{F}=21.6 ; p<0.0001)$, interaction tillage $\times$ vegetation $(\mathrm{F}=4.9 ; p=0.0003)$.

Table 2. Analysis of variance for soil C- $\mathrm{CO}_{2}$ emissions.

\begin{tabular}{cccccc}
\hline Source & DF & Sum of Squares & Mean Square & F Value & Pr $>$ F \\
\hline Model & 25 & Total Model & & \\
Error & 262 & $14,729.3$ & 1497.2 & 26.5 & $<0.0001$ \\
Corrected Total & 287 & $52,227.4$ & 56.5 & & \\
Tillage & 5 & Components of Model & & \\
Time of measurement & 14 & 9791.1 & 1958.2 & 34.7 & $<0.0001$ \\
Vegetation & 1 & 9567.6 & $12,120.0$ & 21.6 & $<0.0001$ \\
Tillage $\times$ vegetation & 5 & 1389.5 & 9563.4 & 169.3 & $<0.0001$ \\
\hline
\end{tabular}

\subsection{Influence of Vegetation on Soil C-CO $\mathrm{CO}_{2}$ Emissions}

During the corn $(n=162)$ growing season, the average annual agroecological factors were: soil temperature $25.0^{\circ} \mathrm{C}$, soil water content $23.3 \%$, air temperature $26.7^{\circ} \mathrm{C}$, relative air humidity $40 \%$. During the winter wheat $(n=126)$ growing season, the average annual agroecological factors were: soil temperature $25.4^{\circ} \mathrm{C}$, soil water content $26.6 \%$, air temperature $28.9^{\circ} \mathrm{C}$, relative air humidity $42 \%$.

Average annual soil C- $\mathrm{CO}_{2}$ emissions were significantly different between studied years and were $40.5 \%$ lower during corn compared to winter wheat cultivation, which is probably a result of higher soil temperatures and soil water content, and, as such, led to greater biological activity during wheat cultivation. Also, the higher planting crop density in wheat resulted in higher and denser root biomass near the soil surface with wheat versus corn thus increasing microbial activity near the soil surface. Emissions amounted to $17.1 \mathrm{~kg} \mathrm{ha}^{-1}$ day $^{-1}$ during corn cultivation, which is in accordance with the value (19.4 $\mathrm{kg} \mathrm{ha}^{-1}$ day $^{-1}$ ) obtained by Ussiri and Lal [22] during corn cultivation in Ohio. During winter wheat growing season, soil C- $\mathrm{CO}_{2}$ emissions amounted to $28.7 \mathrm{~kg} \mathrm{ha}^{-1}$ day $^{-1}$ which is higher than results obtained by Kessavalou et al. [15], who determined that mean annual $\mathrm{CO}_{2}$ emissions from wheat-fallow at Sidney, NE, ranged from 6.9 to $20.1 \mathrm{~kg} \mathrm{C} \mathrm{ha}^{-1}$ day $^{-1}$.

\subsection{Seasonal Pattern of Soil C-CO $\mathrm{CO}_{2}$ Emissions}

Ranges of average monthly agroecological factors and soil C- $\mathrm{CO}_{2}$ emissions in 2012 and 2013 (Figure 2) were, respectively: soil temperatures $3.3-36.6{ }^{\circ} \mathrm{C}$ and $14.6-33.0^{\circ} \mathrm{C}$; soil water content $8.3 \%-36.2 \%$ and $22.6 \%-29.6 \%$; air temperatures $5.7-41.9{ }^{\circ} \mathrm{C}$ and $23.2-34.5^{\circ} \mathrm{C}$; relative air humidity $27 \%-84 \%$ and $30 \%-56 \%$; soil C-CO ${ }_{2}$ emissions $6.2-33.6 \mathrm{~kg} \mathrm{ha}^{-1}$ day $^{-1}$ and $22.1-36.2 \mathrm{~kg} \mathrm{ha}^{-1} \mathrm{day}^{-1}$.

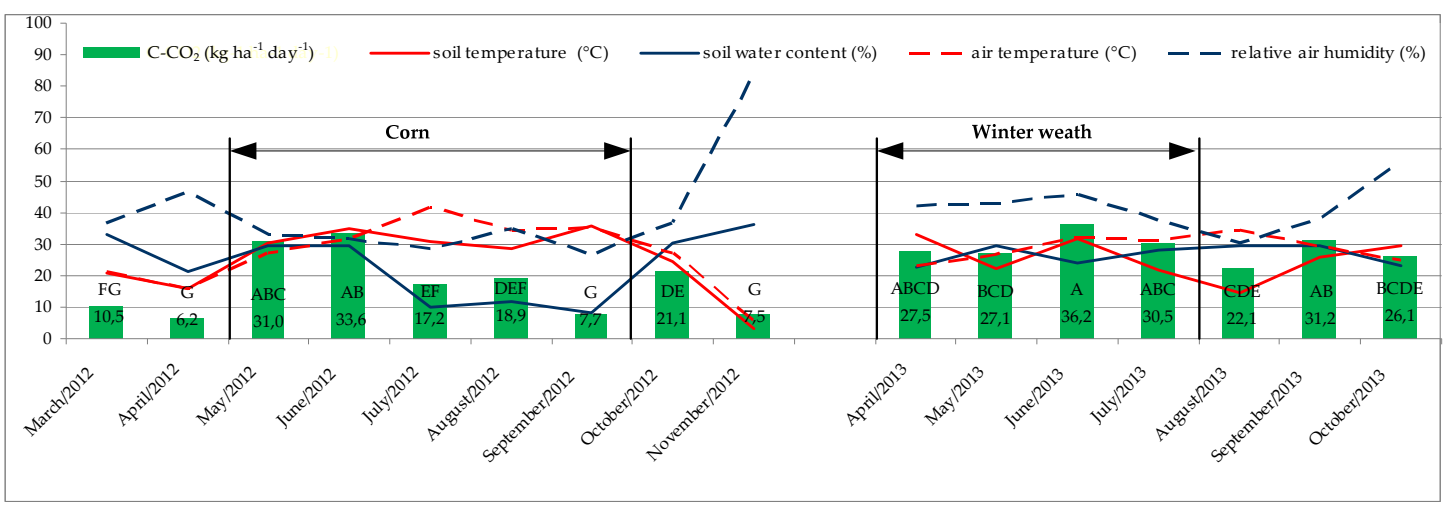

Figure 2. Average monthly soil C- $\mathrm{CO}_{2}$ emissions and agroecological factors in 2012 and 2013 ( $\left.n=18\right)$. (Means followed by the same letter are not significantly different at the $p \leqslant 0.05$ level.) 
In 2012, average seasonal emissions decreased, respectively, summer $>$ spring $>$ autumn $\left(23.2>15.9>12.1 \mathrm{~kg} \mathrm{ha}^{-1} \mathrm{day}^{-1}\right)$ and were significantly higher in the period with crop presence (May-September) compared to the period with crop absence (March, April, October, November). In 2013, average seasonal emissions decreased, respectively, summer $>$ autumn $>$ spring $\left(29.6>28.7>27.3 \mathrm{~kg} \mathrm{ha}^{-1} \mathrm{day}^{-1}\right)$ and were not significantly higher in the period with crop presence (April-July) compared to the period with its absence (August-October). According to literature data, soil $\mathrm{CO}_{2}$ emissions are changing with the exchange of seasons and are dependent on climatological conditions, crop type, soil type and many other factors and they have no clear pattern. Kessavalou et al. [15] measured the highest soil $\mathrm{CO}_{2}$ emissions in spring and the lowest in winter during wheat cultivation in Nebraska; Jacinthe et al. [33] determined with black fallow that soil $\mathrm{CO}_{2}$ emissions decreased winter $>$ summer $>$ autumn in Ohio; Lou et al. [38] recorded, in China, a gradual decrease of soil $\mathrm{CO}_{2}$ emissions from August to January and an increase from January to July, and Ussiri and Lal [22] determined that daily $\mathrm{CO}_{2}$ fluxes were the highest in summer and the lowest in winter, while Bauer et al. [21] determined that $\mathrm{CO}_{2}$ flux rates decreased, respectively, summer $>$ spring $>$ fall.

\subsection{Influence of Tillage Treatment on Soil C-CO Emissions}

Our study showed that tillage treatments affect soil $\mathrm{CO}_{2}$ emissions, which agrees with several other studies $[15,39]$, where $\mathrm{CO}_{2}$ release varied with agricultural practices. Figure 3 presents two-year average soil $\mathrm{C}-\mathrm{CO}_{2}$ emissions $(\mathrm{n}=48)$ considering tillage treatments.

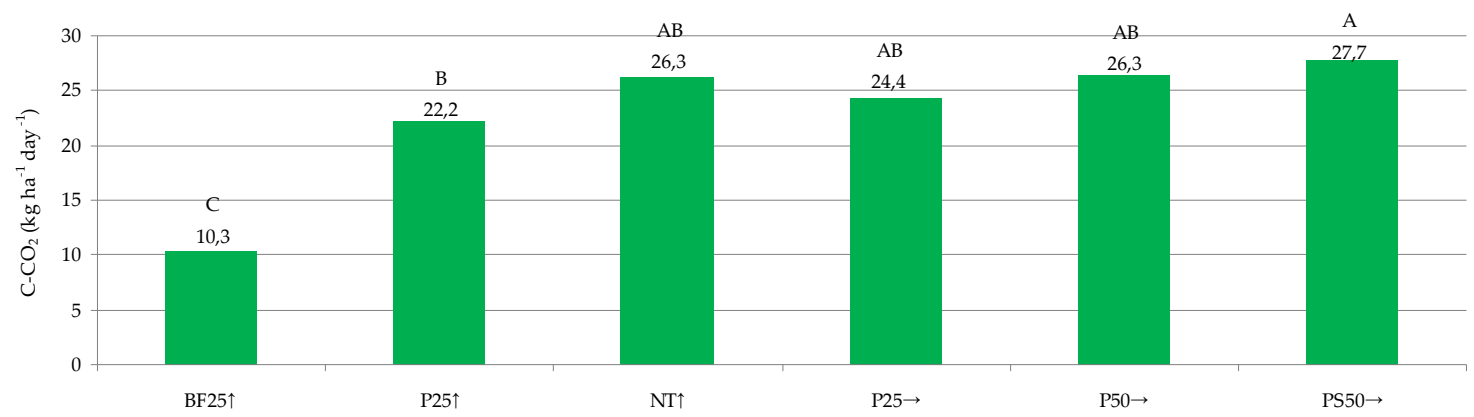

Figure 3. Two-year average soil C- $\mathrm{CO}_{2}$ emissions considering tillage treatment. (Means followed by the same letter are not significantly different at the $p \leqslant 0.05$ level.)

Significantly lower two-year average soil C- $\mathrm{CO}_{2}$ emission was determined at the $\mathrm{BF}_{25} \uparrow$ treatment, which was 2.5 times lower compared to the average soil $\mathrm{CO}_{2}$ emission of treatments with crops. This is in accordance with literature data where $\mathrm{CO}_{2}$ emissions on soils with crop presence were $0.2-3$ times higher compared to bare soil $[10,15,28]$. Comparing treatments with a growing crop, $\mathrm{CO}_{2}$ emissions were lowest with the $\mathrm{P}_{25}{ }^{\uparrow}$ treatment, averaged across two years. In a two-year average, soil C-CO emissions determined at $\mathrm{P}_{25} \uparrow$ and $\mathrm{PS}_{50} \rightarrow$ treatments differed significantly while emissions measured at other studied treatments did not differ significantly. Intensity of soil $\mathrm{CO}_{2}$ release depends on tillage intensity; greater tillage intensity leads to higher emissions [40].

Figure 4 shows the average annual soil C- $-\mathrm{CO}_{2}$ emissions considering tillage treatments in 2012 $(n=27)$ and $2013(n=21)$. Statistical analyses determine that the same tillage treatments significantly differed between studied years except for the $\mathrm{BF}_{25} \uparrow$ treatment. Soil $\mathrm{C}-\mathrm{CO}_{2}$ emissions were lower during corn compared to winter wheat growing season due to crop type, i.e., greater crop canopy has an influence on microbiological and root system activity, and thereby soil $\mathrm{CO}_{2}$ release intensity. Soil $\mathrm{C}-\mathrm{CO}_{2}$ emissions with crop presence varied among tillage treatments when corn was grown, but not when winter wheat was grown (Figure 4). 


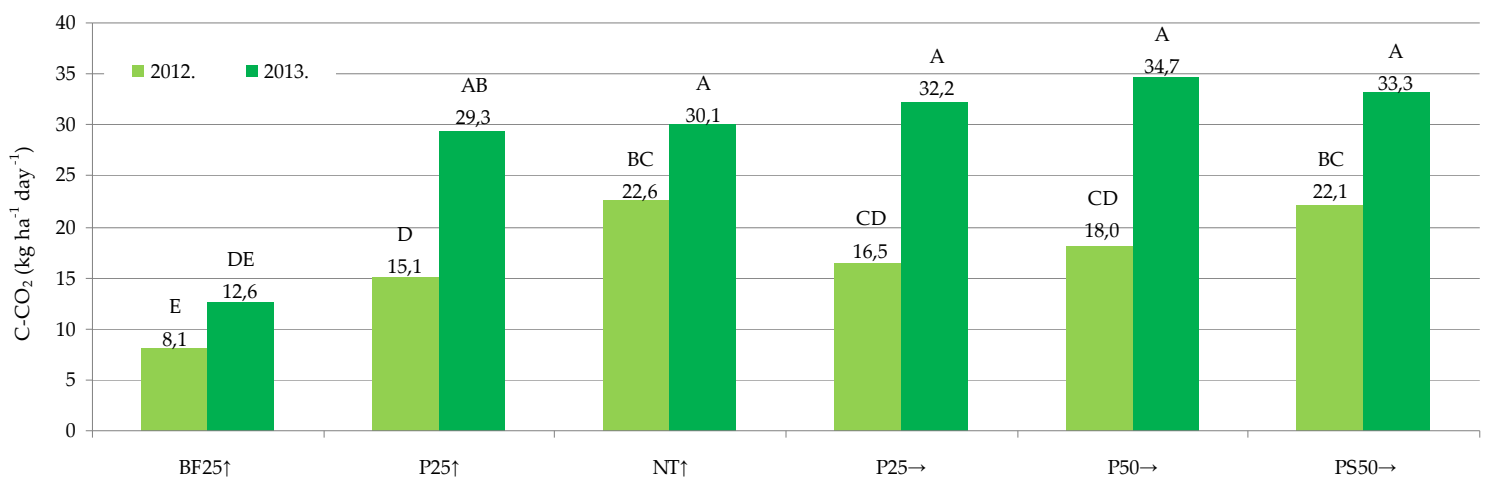

Figure 4. Average annual soil C-CO $\mathrm{CO}_{2}$ emissions in 2012 and 2013 considering tillage treatments. (Means followed by the same letter are not significantly different at the $p \leqslant 0.05$ level.)

Considering the treatments with crop presence, in 2012, during the corn growing season, a significant difference in soil C-CO $\mathrm{CO}_{2}$ emissions was only determined between the $\mathrm{P}_{25} \uparrow$ and $\mathrm{NT}^{\uparrow}$ treatments. The average annual soil C- $\mathrm{CO}_{2}$ emission at $\mathrm{NT}^{\uparrow}$ treatment was $20.6 \%$ higher compared to the average of conventionally tilled treatments. Implementation of no-tillage can increase soil $\mathrm{CO}_{2}$ emissions due to the higher water content maintenance in the soil surface layer which results in greater soil biological activity. Other authors have also determined higher $\mathrm{CO}_{2}$ emissions at no-tillage compared to conventional tillage [25,41].

In 2013, during the winter wheat growing season, soil C- $\mathrm{CO}_{2}$ emissions did not differ significantly between different tillage treatments with crops. However, the average annual soil C- $\mathrm{CO}_{2}$ emission at $\mathrm{NT}^{\uparrow}$ treatment was $7.2 \%$ lower compared to the average of conventionally tilled treatments. Conventional tillage has influence on soil aggregate turnover, improves soil aeration, infiltration, water holding capacity, and increases the contact between soil and crop residues, which results in increased soil $\mathrm{CO}_{2}$ emissions compared to no-tillage. Lower soil C- $\mathrm{CO}_{2}$ emissions at no-tillage compared to conventional tillage have also been determined by many other authors [15,18-21].

Similar results were reported by Franzluebbers et al. [26], who found that $\mathrm{CO}_{2}$ emissions in some years were higher in no-tillage than in conventional tillage, but in other years, the tillage effect was not observed. Vinten et al. [42] determined, in one year of research, higher, and in the other year of research, lower soil C- $\mathrm{CO}_{2}$ emissions at no-tillage compared to conventional tillage. On the other hand, many other authors did not determine any significant differences in soil C- $\mathrm{CO}_{2}$ emissions between mentioned tillage treatments [43-45]. Based on the contrasting results reported in the literature compared to our study, it is apparent that multiple factors must be involved in $\mathrm{CO}_{2}$ emissions. The study of this complex interaction among factors will be helpful in understanding the agricultural impact on $\mathrm{CO}_{2}$ emissions.

\section{Conclusions}

In the research on soil C-CO $\mathrm{CO}_{2}$ emissions at Stagnosols in central lowland Croatia, it was found that the moment of the measurement and crop type have significant influence on soil $\mathrm{C}-\mathrm{CO}_{2}$ emissions. During both studied years, soil C- $\mathrm{CO}_{2}$ emissions were higher in warmer periods of the year compared to the colder ones. The average annual soil $\mathrm{C}-\mathrm{CO}_{2}$ emission was $40.5 \%$ lower during corn compared to winter wheat growing season. According to the results, a significant effect of tillage practices on soil $\mathrm{CO}_{2}$ emissions has been determined during corn but not during winter wheat growing season, so further research is needed to establish such a difference as two years is a short period due to the strong impact of weather. With regard to the soil $\mathrm{CO}_{2}$ emissions, the same tillage methods differed significantly between the studied years. Soil C- $\mathrm{CO}_{2}$ emissions were $20.6 \%$ higher during the corn growing season and $7.2 \%$ lower during the winter wheat growing season at no-till compared to the average of conventionally tilled treatments. In these agroecological conditions, the optimal tillage method with regard to emitted $\mathrm{C}-\mathrm{CO}_{2}$ into the atmosphere is plowing to $25 \mathrm{~cm}$ along the slope; however, we would like to highlight that the formation and release of carbon dioxide from the soil 
does not depend only on one factor, but is a result of very complex interactions between all biotic and abiotic factors of the agroecosystem. It is very important to utilize natural resources in a sustainable way to have satisfactory agricultural production, minimal soil $\mathrm{CO}_{2}$ emissions into the atmosphere and maximal soil carbon sequestration by which climate change could be mitigated.

Acknowledgments: The research was financially supported by Croatian Environmental protection and energy efficiency Fund and Ministry of Science, Education and Sports of the Republic of Croatia. We have received a part of funds from Croatian Environmental protection and energy efficiency Fund for covering the costs to publish in open access.

Author Contributions: Ivica Kisić and Željka Zgorelec conceived and designed the experiment; Željka Zgorelec contributed reagents/materials/analysis tools; Darija Bilandžija performed the experiments, analyzed the data and wrote the paper.

Conflicts of Interest: The authors declare no conflict of interest. The founding sponsors had no role in the design of the study; in the collection, analyses, or interpretation of data; in the writing of the manuscript, and in the decision to publish the results.

\section{References}

1. Lal, R. Restoring Soil Quality to Mitigate Soil Degradation. Sustainability 2015, 7, 5875-5895. [CrossRef]

2. Mielnick, P.C.; Dugas, W.A. Soil $\mathrm{CO}_{2}$ flux in a tallgrass prairie. Soil Biol. Biochem. 1999, 32, 221-228. [CrossRef]

3. Maier, C.A.; Kress, L.W. Soil $\mathrm{CO}_{2}$ evolution and root respiration in 11 year-old loblolly pine (Pinus taeda) plantations as affected by moisture and nutrient availability. Can. J. For. Res. 2000, 30, 347-359. [CrossRef]

4. Mesić, M.; Birkas, M.; Zgorelec, Ž.; Kisić, I.; Jurišić, A.; Šestak, I. Carbon content and C/N ratio in Pannonian and Mediterranean soils. In Impact of Tillage and Fertilization on Probable Climate Threats in Hungary and Croatia, Soil Vulnerability and Protection; Birkas, M., Mesić, M., Eds.; Szent Istvan University Press: Godollo, Hungary, 2012; pp. 45-53.

5. Jensen, L.S.; Mueller, T.; Tate, R.K.; Riss, D.J.; Magid, J.; Nelson, N.E. Soil surface $\mathrm{CO}_{2}$ flux as an index of soil respiration in situ: A comparison of two chamber methods. Soil Biol. Biochem. 1996, 28, 1297-1306. [CrossRef]

6. Caldeira, K.; Morgan, M.G.; Baldocchi, D.; Brewer, P.G.; Chen, C.T.A.; Nabuurs, G.J.; Nakicenovic, N.; Robertson, G.P. A portfolio of carbon management options. In The Global Carbon Cycle; Field, C.B., Raupach, M.R., Eds.; Island Press: Washington, DC, USA, 2004; pp. 103-109.

7. Almagro, M.; Querejeta, J.I.; Boix-Fayos, C.; Martínez-Mena, M. Links between vegetation patterns, soil $\mathrm{C}$ and $\mathrm{N}$ pools and respiration rate under three different land uses in a dry Mediterranean ecosystem. J. Soils Sediments 2013, 13, 641-653. [CrossRef]

8. Oorts, K.; Merckx, R.; Grehan, E.; Labreuche, J.; Nicolardot, B. Determinants of annual fluxes of $\mathrm{CO}_{2}$ and $\mathrm{N} 2 \mathrm{O}$ in long-term no-tillage and conventional tillage systems in northern France. Soil Till. Res. 2007, 95, 133-148. [CrossRef]

9. Duxbury, J.M. The significance of agricultural sources of greenhouse gases. Fert. Res. 1994, 38, 151-163. [CrossRef]

10. Rastogi, M.; Singh, S.; Pathak, H. Emission of carbon dioxide from soil. Curr. Sci. 2002, 82, 510-517.

11. Lal, R. Global potential of soil carbon sequestration to mitigate the greenhouse effect. Plant Sci. 2003, 22, 151-184. [CrossRef]

12. Luo, Y.; Zhou, X. Soil Respiration and the Environment; Elsevier: London, UK, 2006; p. 316.

13. Jarecki, M.K.; Lal, R. Compost and mulch effects on gaseous flux from an alfisol in Ohio. Soil Sci. 2006, 171, 249-260. [CrossRef]

14. Birkás, M. Environmentally-Sound Adaptable Tillage-Solutions from Hungary; Akademiai Kiado: Budapest, Hungary, 2008; pp. 191-194.

15. Kessavalou, A.; Mosier, A.R.; Doran, J.W.; Drijber, R.A.; Lyon, D.J.; Heinemeyer, O. Fluxes of Carbon Dioxide, Nitrous Oxide, and Methane in Grass Sod and Winter Wheat-Fallow Tillage Management. J. Environ. Qual. 1998, 27, 1094-1104. [CrossRef]

16. Rochette, P.; Angers, D.A. Soil surface carbon dioxide fluxes induced by spring, summer, and fall moldboard plowing in a sandy loam. Soil Sci. Soc. Am. J. 1999, 63, 621-628. [CrossRef]

17. La Scala, A.; Lopes, K.; Bolonhezi, D.; Archer, D.W.; Reicosky, D.C. Short-temporal changes of soil carbon losses after tillage described by a first-order decay model. Soil Till. Res. 2008, 99, 108-118. 
18. Jabro, J.D.; Sainju, U.; Stevens, W.B.; Evans, R.G. Carbon dioxide flux as affected by tillage and irrigation in soil converted from perennial forages to annual crops. J. Environ. Manag. 2008, 88, 1478-1484. [CrossRef] [PubMed]

19. Curtin, D.; Wang, H.; Selles, F.; Mcconkey, B.G.; Campbell, C.A. Tillage Effects on Carbon Fluxes in Continuous Wheat and Fallow-Wheat Rotations. Soil Sci. Soc. Am. J. 2000, 64, 2080-2086. [CrossRef]

20. Al-Kaisi, M.M.; Yin, X. Tillage and Crop Residue Effects on Soil Carbon and Carbon Dioxide Emission in Corn-Soybean Rotations. J. Environ. Qual. 2005, 34, 437-445. [CrossRef] [PubMed]

21. Bauer, P.J.; Frederick, J.R.; Novak, J.M.; Hunt, P.G. Soil $\mathrm{CO}_{2}$ flux from a Norfolk loamy sand after 25 years of conventional and conservation tillage. Soil Till. Res. 2006, 90, 205-211. [CrossRef]

22. Ussiri, D.A.N.; Lal, R. Long-term tillage effects on soil carbon storage and carbon dioxide emissions in continuous corn cropping system from an alfisol in Ohio. Soil Till. Res. 2009, 104, 39-47. [CrossRef]

23. Paustian, K. Agricultural soils as a sink to mitigate $\mathrm{CO}_{2}$ emissions. Soil Use Manag. 1997, 13, $230-244$. [CrossRef]

24. Ball, B.C.; Scott, A.; Parker, J.P. Field $\mathrm{N}_{2} \mathrm{O}, \mathrm{CO}_{2}$ and $\mathrm{CH}_{4}$ fluxes in relation to tillage, compaction and soil quality in Scotland. Soil Till. Res. 1999, 53, 29-39. [CrossRef]

25. Hendrix, P.F.; Han, C.R.; Groffman, P.M. Soil respiration in conventional and no-tillage agroecosystems under different winter cover crop rotations. Soil Till. Res. 1988, 12, 135-148. [CrossRef]

26. Franzluebbers, A.J.; Hons, F.M.; Zuberer, D.A. Tillage induced seasonal changes in soil physical properties affecting soil $\mathrm{CO}_{2}$ evolution under intensive cropping. Soil Till. Res. 1995, 34, 41-60. [CrossRef]

27. Bilandžija, D.; Zgorelec, Ž.; Kisić, I. The Influence of Agroclimatic Factors on Soil $\mathrm{CO}_{2}$ Emissions. Collegium Antropol. 2014, 38, 77-83.

28. Raich, J.W.; Tufekcioglu, A. Vegetation and soil respiration: Correlations and controls. Biogeochemistry 2000, 48, 71-90. [CrossRef]

29. Schlesinger, W.H.; Andrews, J.A. Soil respiration and the global carbon cycle. Biogeochemistry 2000, 48, 7-20. [CrossRef]

30. Amos, B.; Arkebauer, T.J.; Doran, J.W. Soil surface fluxes of greenhouse gases in an irrigated maize-based agroecosystem. Soil Sci. Soc. Am. J. 2005, 69, 387-395. [CrossRef]

31. Johnson, J.M.; Franzluebbers, A.J.; Lachnicht-Weyers, S.; Reicosky, D.C. Agricultural opportunities to mitigate greenhouse gas emissions. Environ. Pollut. 2007, 150, 107-124. [CrossRef] [PubMed]

32. Bajracharya, R.M.; Lal, R.; Kimble, J.M. Diurnal and seasonal $\mathrm{CO}_{2}-\mathrm{C}$ flux from soil as reflected to erosion phases in central Ohio. Soil Sci. Soc. Am. J. 2000, 64, 286-293. [CrossRef]

33. Jacinthe, P.A.; Lal, R.; Kimble, J.M. Carbon budget and seasonal carbon dioxide emission from a central Ohio Luvisol as influenced by wheat residue amendment. Soil Till. Res. 2002, 67, 147-157. [CrossRef]

34. Wan, S.; Hui, D.; Wallace, L.L.; Luo, Y. Direct and indirect warming effects on ecosystem carbon processes in a tallgrass prairie. Glob. Biogeochem. Cycles 2005, 19. [CrossRef]

35. IUSS Working Group WRB. World Reference Base for Soil Resources 2006; World Soil Resources Report; FAO: Rome, Italy, 2010.

36. Gajić-Čapka, M.; Zaninović, K. Climate. In Climate Atlas of Croatia 1961-1990, 1971-2000; Zaninović, K., Ed.; Meteorological and Hydrological Service: Zagreb, Croatia, 2008; pp. 11-15.

37. SAS Institute. SAS 9.1.3; Help and Documentation: Cary, NC, USA, 2002-2004.

38. Lou, Y.; Li, Z.; Zhang, T. Carbon Dioxide Flux in a Subtropical Agricultural Soil of China. Water Air Soil Poll. 2003, 149, 281-293. [CrossRef]

39. Syp, A.; Faber, A.; Pikula, D. Assessing the impact of management practices on gas emissions and N losses calculated with denitrification-decomposition model. Plant Soil Environ. 2015, 61, 433-437. [CrossRef]

40. Bilen, S.; Celik, A.; Altikat, S. Effects of strip and full-width tillage on soil carbon IV oxide-carbon $\left(\mathrm{CO}_{2}-\mathrm{C}\right)$ fluxes and on bacterial and fungal populations in sunflower. Afr. J. Biotechnol. 2010, 9, 6312-6319.

41. Liu, X.J.; Mosier, A.R.; Halvorson, A.D.; Zhang, F.S. The impact of nitrogen placement and tillage on NO, $\mathrm{N}_{2} \mathrm{O}, \mathrm{CH}_{4}$ and $\mathrm{CO}_{2}$ fluxes from a clay loam soil. Plant Soil 2006, 280, 177-188. [CrossRef]

42. Vinten, A.J.A.; Ball, B.C.; O'Sullivan, M.F.; Henshall, J.K.; Howard, R.; Wright, F.; Ritchie, R. The effects of cultivation method and timing, previous sward and fertilizer level on subsequent crop yields and nitrate leaching following cultivation of long-term grazed grass and grass-clover swards. J. Agric. Sci. 2002, 139, 245-256. [CrossRef] 
43. Aslam, T.; Choudhary, M.; Saggar, S. Influence of land-use management on $\mathrm{CO}_{2}$ emissions from a silt loam soil in New Zealand. Agric. Ecosyst. Environ. 2000, 77, 257-262. [CrossRef]

44. Omonode, R.A.; Vyn, T.J.; Smith, D.R.; Hegymegi, P.; Gal, A. Soil carbon dioxide and methane fluxes from long-term tillage systems in continuous corn and corn-soybean rotations. Soil Till. Res. 2007, 95, 182-195. [CrossRef]

45. Elder, J.W.; Lal, R. Tillage effects on gaseous emissions from an intensively farmed organic soil in North Central Ohio. Soil Till. Res. 2008, 98, 45-55. [CrossRef]

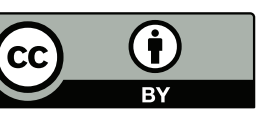

(c) 2016 by the authors; licensee MDPI, Basel, Switzerland. This article is an open access article distributed under the terms and conditions of the Creative Commons by Attribution (CC-BY) license (http:/ / creativecommons.org/licenses/by/4.0/). 